\title{
Absence of Mycobacterium tuberculosis DNA in synovial fluid from patients with rheumatoid arthritis
}

\author{
Hamid Jalal, Michael Millar, Chris Linton, Paul Dieppe
}

\begin{abstract}
Objectives-To determine whether Mycobacterium tuberculosis DNA can be detected in synovial fluid of patients with rheumatoid arthritis (RA).

Methods-The polymerase chain reaction was applied to cellular components of synovial fluid.

Results-No evidence of $M$ tuberculosis DNA was found in synovial fluid from 31 patients with RA and 13 control patients. Conclusion-The findings do not support a role for persistent $M$ tuberculosis infection in the pathogenesis of RA.
\end{abstract}

(Ann Rheum Dis 1994; 53: 695-698)

The aetiology of rheumatoid arthritis (RA) remains unknown, but the possible role of an infectious agent either as a trigger to the disease, or as a persistent antigenic drive to inflammatory synovitis has not been ruled out. Evidence from laboratory animals has suggested that $M$ tuberculosis could be involved in the pathogenesis of arthritis. Autoimmune arthritis can be induced in MHC susceptible rats by inoculation with $M$ tuberculosis ${ }^{1}$ and the disease can be transferred to naive animals by $M$ tuberculosis specific $\mathrm{T}$ lymphocyte clones ${ }^{2}$ from inoculated rats. $T$ cell clones isolated from Lewis rats with adjuvant-induced arthritis have been shown to proliferate in response to the $65 \mathrm{KDa}$ protein of $M$ tuberculosis $^{3}$ and $\mathrm{T}$ lymphocytes of RA patients have been reported to show augmented reactivity to an antigen of $M$ tuberculosis $^{4}$. IgG and IgA antibodies to the $65 \mathrm{KDa}$ protein of $M$ tuberculosis in RA are also reported to be significantly higher than in patients with systemic lupus erythematosus, Crohn's disease or healthy controls, ${ }^{5}$ suggesting that immune responses to the $65 \mathrm{KDa}$ protein may be involved in the initiation or maintenance of RA.

In the present work, we looked for the presence of $M$ tuberculosis in synovial fluid of patients with RA by using the polymerase chain reaction (PCR).

\section{Patients and methods}

PATIENTS

Synovial fluid samples from 31 patients fulfilling the American Rheumatism Association Criteria (1987) for definite RA were screened by PCR, for the presence of $M$ tuberculosis
DNA. As a comparative group 13 patients (reactive arthritis $=4$, psoriatic arthritis $=4$, osteoarthritis $=2$, ankylosing spondylitis $=2$, gout $=1$ ) were studied. The characteristics of the patients studied are shown in the table.

Synovial fluid was aspirated using an aseptic technique. The needle was removed and the syringe capped, coded and sent to the laboratory within two hours. The cap of the syringe containing synovial fluid was removed in a Category II, laminar flow cabinet, dedicated for this purpose. Synovial fluid was divided into aliquots of $0.5 \mathrm{ml}$ and stored at $-70^{\circ} \mathrm{C}$.

EXTRACTION OF DNA FROM CELLULAR

COMPONENT OF SYNOVIAL FLUID

After washing with analar water (BDH), the cell pellets from $500 \mu$ l of synovial fluid were treated with Hirt buffer $(0.01 \mathrm{M}$ tris, $0.01 \mathrm{M}$ EDTA pH 8 $0,0 \cdot 6 \%$ sodium dodecyl sulphate, SDS) and proteinase $\mathrm{K}(50 \mu \mathrm{g} / \mathrm{ml})$, followed by incubation at $37^{\circ} \mathrm{C}$ from 12 to 18 hours. The cell lysate was then extracted three times with phenol/chloroform (1:1 mixture), and DNA was precipitated by addition of $20-50 \mu \mathrm{g}$ of glycogen (Boehringer Mannheim), 1/10 volume of $5 \mathrm{M}$ ammonium acetate and 0.8 volume of isopropanol. The DNA precipitate was washed in $70 \%$ ethanol, dried and redissolved in $100 \mu$ l analar water.

POLYMERASE CHAIN REACTION USING PRIMERS FROM HUMAN APRT GENE

The PCR reaction mixture contained $10 \mathrm{mM}$ Tris $\mathrm{pH} \mathrm{9,} 50 \mathrm{mM} \mathrm{KCl}, 1.5 \mathrm{mM} \mathrm{MgCl}_{2}$, $20 \mu \mathrm{M}$ of each dNTP, $0.05 \mu \mathrm{M}$ of each primer, 0.25 units of supertaq polymerase (HT Biotechnology Ltd) and $5 \mu \mathrm{l}$ of template DNA.

The samples were subjected to 30 cycles of amplification in an OmniGene-Hybaid Thermal Cycler as follows. Before the start of cycling the DNA was denatured for three minutes at $94^{\circ} \mathrm{C}$. In each cycle denaturation was $94^{\circ} \mathrm{C}$ for 30 seconds, annealing of primers to the target DNA was carried at $63^{\circ} \mathrm{C}$ for one minute and synthesis at $72^{\circ} \mathrm{C}$ for one minute. At the end of 30 cycles the tubes were heated at $72^{\circ} \mathrm{C}$ for seven minutes.

Special care was taken to avoid contamination of samples with amplicons. Clinical material was handled in a category II laminar flow hood, dedicated for this purpose. The preparation of PCR reaction mixture and 
Characteristics of the patients studied

\begin{tabular}{|c|c|c|c|c|}
\hline Diagnosis & No & $M / F$ & $\begin{array}{l}\text { Median age } \\
\text { (range) }\end{array}$ & $\begin{array}{l}\text { Duration of } \\
\text { disease }\end{array}$ \\
\hline \multicolumn{5}{|c|}{ Clinical details of experimental group } \\
\hline Rheumatoid Arthritis & 4 & $0 / 4$ & 25 Years $(18-59)$ & $<2$ Years \\
\hline Rheumatoid Arthritis & 12 & $9 / 3$ & 64 Years $(32-80)$ & $2-10$ Years \\
\hline Rheumatoid Arthritis & 15 & $5 / 10$ & 69 Years $(33-79)$ & $>10$ Years \\
\hline \multicolumn{5}{|c|}{ Clinical details of control group } \\
\hline Reactive arthritis & 2 & $2 / 0$ & 18 and 52 Years & $<2$ Years \\
\hline Reactive arthritis & 2 & $1 / 2$ & 30 and 36 Years & $2-10$ Years \\
\hline Psoriatic arthritis & 1 & $1 / 0$ & 54 Years & $<2$ Years \\
\hline Psoriatic arthritis & 2 & $1 / 1$ & 75 and 35 Years & $2-10$ Years \\
\hline Psoriatic arthritis & 1 & $1 / 0$ & 30 Years & $>10$ Years \\
\hline Osteoarthritis & 1 & $0 / 1$ & 69 Years & $2-10$ Years \\
\hline Osteoarthritis & 1 & $0 / 1$ & 61 Years & $>10$ Years \\
\hline Ankylosing spondylitis & 2 & $2 / 0$ & 62 Years & $>10$ Years \\
\hline Gout & 1 & $0 / 1$ & 59 Years & $>10$ Years \\
\hline
\end{tabular}

pipetting of samples were performed in a category II laminar flow hood situated in a separate room with restricted passage of personnel and decontamination barriers including changing of protective clothing on entering. The analysis of PCR products was performed in another laboratory room. Special emphasis was placed on preventing carryover of amplicons from post-PCR to pre-PCR facilities. To prevent aerosal contamination of pipettes aerogard tips with a barrier (Alpha Laboratories Ltd) were used in pipetting specimens.

Primers used in this study were designed by using PCR and Oligo Primer Design Program (Scientific Educational Software, USA). The DNA sequences of primers employed were as follows (reading from 5' to $3^{\prime}$ ).

Human APRT gene (amplifies: 329 bp from bp 1198-1527)

\section{(1) CTTCTTGTTCCTTCTGCGAG \\ (2) TGGCCTGAGCTGTGATGGTT}

POLYMERASE CHAIN REACTION USING PRIMERS FROM A REPETITIVE DNA SEQUENCE SPECIFIC FOR $M$ TUBERCULOSIS

Each DNA sample from cellular components of synovial fluid was spiked with $5 \mathrm{pg}$ of $M$ tuberculosis DNA to investigate the presence of PCR inhibitors in it. PCR was performed on spiked and unspiked samples as described by Eisenach et al. ${ }^{6}$

DETECTION OF AMPLIFIED PRODUCTS

Fifteen $\mu l$ of each PCR product was analysed by gel electrophoresis in a $2 \%$ agarose gel using tris borate buffer $(89 \mathrm{mM}$ tris, $89 \mathrm{mM}$ boric acid $\mathrm{pH} 7.8$ ). The amplified products were visualised by staining the gel with ethidium bromide $(0.5 \mu \mathrm{g} / \mathrm{ml}$ in tris borate buffer) and inspected under UV illumination.

\section{Results}

SUITABILITY OF DNA FOR AMPLIFICATION

To exclude possible false negative results caused by absences of template DNA, PCR was performed using primers specific for the human adenosine phosphoribosyl transferase (APRT) gene. Of the 44 synovial fluid samples investigated in this study, 37 contained amplifiable DNA. An example of the results is shown in fig 1 .

PCR TO DE'TECT M TUBERCLLOSIS INNA IN SYNOVIAI, IILUID

Spiked samples

PCR was performed on all 44 samples spiked with $M$ tuberculosis DNA, using primers specific for $M$ tuberculosis under highly stringent PCR conditions. The sensitivity and specificity of PCR assay used in this study has been described elsewhere. ${ }^{6}$ All spiked samples gave positive results. An example of the results is shown in fig 2 .

Unspiked samples

PCR was also performed on all 44 unspiked samples. None of the unspiked synovial fluid sample contained $M$ tuberculosis DNA. An example of the results is shown in fig 3 .

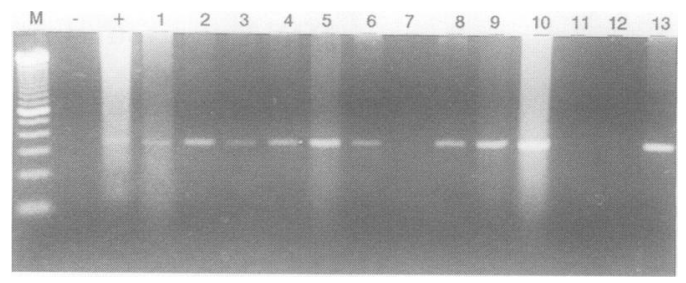

Figure 1 Results of $P C R$ reaction, using primers from human APRT gene as analysed by' gel electrophoresis. Positive control (human lymph node DNA, shown in + track) and negative control (no DNA, shown in - track) gave expected results. Experimental samples of synovial fluid DNA preparation are shown in tracks 1 i.3.

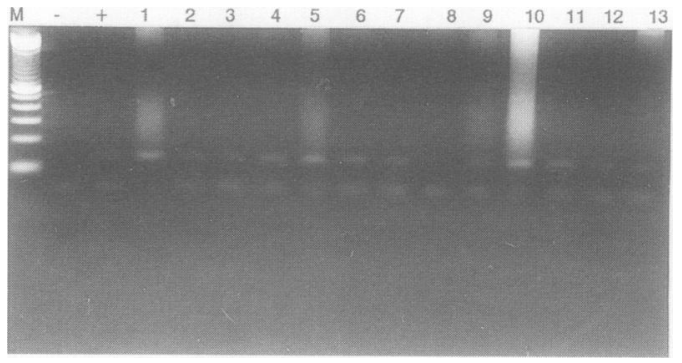

Figure 2 Results of $P C R$ reaction using primers from repetitive DNA sequences of $\mathrm{M}$ tuberculosis. Positive control (M tuberculosis DNA, shown in + track) and negative control (no DNA, shown in-track) gave expected results. Experimental samples of synovial fluid $D N A$ preparation spiked with $\mathrm{M}$ tuberculosis $D N A$ are shown in tracks 1-1.3.

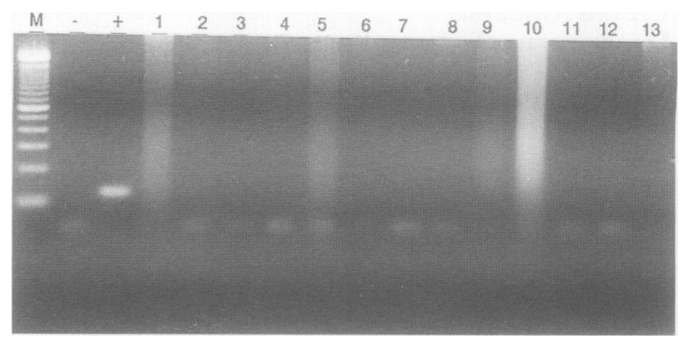

Figure 3 Results of $P C R$ reaction using primers from repetitive DNA sequences of $\mathrm{M}$ tuberculosis. Positive control (M tuberculosis DNA, shown in + track) and negative control (no DNA, shown in - track) gave expected results. Experimental samples of synovial fluid DNA preparation are shown in tracks $1-13$.

Experimental samples in fig 1,2 and 3 correspond to each other. Size of PCR products was measured relative to the $100 \mathrm{bp}$ DNA ladder shown in track $M$. 
To ensure the reproducibility and reliability of PCR, positive and negative controls were included in each experiment. Positive control for PCR using primers from human APRT gene was DNA extracted from a pelvic lymph node and for PCR using primers from repetitive DNA sequence of $M$ tuberculosis was pure growth of recent clinical isolate of $M$ tuberculosis. Negative controls contained all the ingredients of PCR except DNA which was replaced by equal volume of analar water. All controls gave appropriate results (figs 1, 2 and 3 ).

\section{Discussion}

The potential role of microbes in the aetiology of RA has been highlighted by the demonstration of microbial components at the site of inflammation in reactive arthritis. This has been documented in arthritides following infection with Chlamydia, Yersinina, Salmonella and Shigella. ${ }^{7-10}$ Borrelia burgdorferi DNA has also been detected in synovial fluids of patients with Lyme arthritis by PCR. ${ }^{11}$

Although evidence from laboratory animals has suggested a possible role of $M$ tuberculosis in RA, in this study its DNA was not detected by PCR in the cellular components of any synovial fluid from 31 RA patients or 13 cases with other forms of arthritis. Isolation of cytotoxic T cells clones crossreactive with $M$ bovis and human hsp 60 from the joints of RA patients suggests a role of autoreactive $T$ cells directed against self-hsp in the pathogenesis of some forms of chronic inflammatory arthritis. ${ }^{12}$ However, this view has been questioned. First, it appears that synovial fluid $\mathrm{T}$ cells reactive with hsp 60 in human RA generally recognise nonconserved bacterial rather than shared (or human) epitopes; ${ }^{13}$ second, at least some $T$ cells responses to recombinant mycobacterial hsp 60 may be directed against contaminating $E$ coli antigens rather than hsp 60 itself; ${ }^{14}$ finally the frequency of $T$ cells reactive with mycobacterial hsp 60 appears to be virtually identical in blood and synovial fluid of patients with RA casting doubt on previous suggestions of local expansion of hsp-reactive $T$ cells in the disease. ${ }^{15}$ The role of molecular mimicry between $M$ tuberculosis and humans hsp 60 proteins is far from clear.

The PCR assay used in this study is highly sensitive and specific. It is able to detect a single copy of $M$ tuberculosis chromosome from a mixture of human and bacterial DNA. ${ }^{6}$ Extreme care was taken to code the samples, ensuring that the reactions were carried out without bias, with the inclusion of positive and negative controls and comparison of results between different PCR runs. While false positive results are a common source of concern in PCR, a frequent source of false negative results in survey of this type is sampling variability, which results in either no DNA or DNA which is unsuitable for the PCR reaction. This possibility was ruled out by employing primers from a cellular gene (APRT). Thirty seven of forty four synovial fluid samples gave positive results, showing that the DNA from these samples was sufficient to act as a PCR template. The possibility of PCR inhibitors in DNA prepared from synovial fluid was also investigated by spiking each sample with $M$ tuberculosis DNA. All 44 samples including seven samples which gave negative result with PCR using primers from APRT gene, produced an expected band of 123 bp showing absence of inhibitors in DNA preparation (fig 2). This shows that the DNA extraction method used in this study removes PCR inhibitors and does not reduce the amplifiability of the DNA template. Seven samples which gave negative result with PCR using primers from APRT gene shows the absence of DNA rather than the presence of PCR inhibitors in amplification reaction. Therefore a negative result in the rest of 37 samples, using the primers for $M$ tuberculosis, would probably be due to absence of $M$ tuberculosis DNA and not to a total lack of DNA.

Persistent infection at sites other than joints can cause reactive arthritis. ${ }^{16}$ This possibility has not been excluded by this study. Absence of $M$ tuberculosis DNA in synovial fluid from patients with RA also does not exclude the presence of $M$ tuberculosis DNA in synovial membranes. Although the techniques used in this study could be used to identify the presence of microbial DNA in synovium, it was not considered ethical to collect samples of synovium from the patients included in this study.

Our findings do not support the persistent involvement of $M$ tuberculosis in the aetiopathogenesis of RA. However, its role as a triggering factor in a genetically or otherwise predisposed host cannot be ruled out.

This study was supported by The Nuffield Foundation.

1 Le Meur M, Berlinger P G, Benoist C, Mathis D. Correcting an immune-response deficiency by creating $\mathrm{E} \alpha$ gene transgenic mice. Nature 1985; 316: 38-42.

2 Holoshitz J, Matitiau A, Cohen I R. Arthritis induced in rats by cloned $\mathrm{T}$ lymphocytes responsive to mycobacteria but not to collagen type II. $\mathcal{f}$ Clin Invest 1984; 75: 211-25.

3 Cohen I R, Holoshitz J, Van Eden W, Frenkal A. $T$ lymphocyte clones illuminate pathogenesis and effect therapy of experimental arthritis. Arthritis Rheum 1985; 28: $841-5$.

4 Holoshitz J, Klajman A, Drucker I, et al. T lymphocytes of rheumatoid arthritis patients show augmented reactivity to a fraction of mycobacteria cross-reactive with cartilage. Lancet 1986; ii: 305-9.

5 Tsoulfa G, Rook G A W, Van-Embden J D A, et al. Raised serum IgG and IgA antibodies to mycobacterial antigens in rheumatoid arthritis. Ann Rheum Dis 1989; 48: 118-23.

6 Eisenach K D, Cave M D, Bates J H, Crawford J T. Polymerase chain reaction amplification of a repetitive DNA sequence specific for Mycobacterium tuberculosis. 7 Infect Dis 1990; 161: 977-80.

7 Keat A, Thomas B, Dixey J, Osborn M, Sonnex C, TaylorRobinson D. Chlamydia trachomatis and reactive arthritis: The missing link. Lancet 1987; i: 72-4

8 Granfors K, Jalkanen S, von Essen R, et al. Yersina antigens in synovial fluid cells from patients with reactive arthritis. N Engl f Med 1989; 320: 216-21.

9 Granfors K, Jalkanen S, Lindberg A A, et al. Salmonella lipopolysaccaride in synovial cells from patients with reactive arthritis. Lancet 1990; 335: 685-8.

10 Granfors K, Jalkanen S, Toivanen P, Koski J, Lindberg A A Bacterial lipopolysaccaride in synovial fluid cells in shigella triggered reactive arthritis. 7 Rheumatol 1992; 19 ; 500 .

11 Nocton J J, Dressler F, Rutledge B J, Rys P N, Persing D H, Steere A C. Detection of Borrelia Burgdorferi DNA by polymerase chain reaction in synovial fluid from patients with Lyme arthritis. $N$ Engl $f$ Med 1994; 330: 229-34. 
12 Li S G, Quayle A J, Shen Y, et al. Mycobacteria and human heat shock protein-specific cytotoxic lymphocytes in 35: 270-81.

13 Pope R M, Lovis R M, Gupta R S. Activation of synovial fluid $\mathrm{T}$ lymphocytes by $60-\mathrm{kD}$ heat-shock proteins with inflammatory synovaitis. Arthritis Rheum 1992; 35: 43-8.

14 Res P C, Breedveld F S, Van Embden J D A. Synovial fluid $\mathrm{T}$ cell reactivity against $65 \mathrm{kD}$ heat-shock protein of mycobacteria in early rheumatoid arthritis. Lancet 1988; 2: $478-80$
15 Fischer H P, Sharrock C E M, Colston M J, et al. Limiting dilution analysis of proliferative $T$ cell responses to mycobacterial $65 \mathrm{kDa}$ heat-shock protovial fluid and peripheral blood of patients with rheumatoid arthritis. Eur f Immunol 1991; 21: $2937-44$

16 Rook G A W, Lydyard P M, Stanford J L. A reappraisal of the evidence that rheumatoid arthritis and several other idiopathic diseases are slow bacterial infections. Ann Rheum Dis 1993; 52: S30-8. 